\title{
UCZEŃ CZY KSIAZŻKA? PEDAGOGIKA JACKA WORONIECKIEGO JAKO PODPOWIEDŹ DLA WSPOŁCZESNYCH SYSTEMÓW WYCHOWANIA
}

\begin{abstract}
Streszczenie: Celem artykułu jest rozważenie aktualności etyki Jacka Woronieckiego ze względu na obecny w niej postulat kształtowania ludzkiego charakteru. Artykuł składa się z dwóch części. Pierwsza jest poświęcona definicji sprawności (kompetencji) moralnej, a druga ukazuje problem kompetencji moralnej w konfrontacji z katalogiem współczesnych wartości. Idąc za rozwiązaniami Woronieckiego, autorka podejmuje próbę określenia kompetencji moralnej jako dynamicznego zespołu cnót, tj. wypracowanych uzdolnień do wybierania i ochrony dobra moralnego. Według niej na kompetencję moralną składają się gotowość do spełniania jakiegoś działania oraz siła ją wyzwalająca. Ponieważ posiadanie tak określonych kompetencji moralnych łączy się z aktywizacją wysiłku autowychowawczego i rozwojem silnego charakteru, autorka uważa, że etyka Woronieckiego odpowiada na potrzeby współczesnej kultury o wysokim stopniu zindywidualizowania. Docenia także postulat Woronieckiego, aby osadzić proces wychowania na mocnym autorytecie moralnym wychowawcy: w systemie edukacji książkowa wiedza nie może zastąpić rzeczywistych relacji między uczniem a mistrzem.
\end{abstract}

Słowa kluczowe: etyka charakteru, cnoty, kompetencje moralne, nowoczesność, personalizm.

Ilekroć chcemy skorzystać w teorii wychowania czy też w pracy wychowawczej z dorobku pedagoga, którego myśl dzieli od naszych czasów przynajmniej kilka dekad, należy postawić sobie pytanie o zakres takiego działania. Zasadnie będzie przyjąć, że inspiracje niekoniecznie muszą być dosłowne, że muszą być kalką czyichś myśli. Jeśli refleksja nad dorobkiem ma być pogłębiona, musimy, rzecz jasna, sięgać do istoty sprawy, podążać tropami autora, zachowując logikę wywodu.

W przypadku bogatej spuścizny Jacka Woronieckiego chodzi przede wszystkim o konstatację, na czym - według autora - polega piękno człowieka jako człowieka oraz jak kształtują się zależności między wypracowaną przez niego teorią wychowania a założoną antropologią. Interesujące podpowiedzi dla pedagogiki uzyskamy dzięki odniesieniu tych ustaleń do kontekstu współczesnej kultury. Śledząc 
dynamikę rozwoju twórczości Woronieckiego, trudno nie zauważyć wysiłku, jaki włożył, aby pokazać aktualność antropologii tomistycznej ${ }^{1}$. Dzięki temu możemy znaleźć u Woronieckiego pewien wzór twórczego powrotu do tradycji, który polega na uważnej obserwacji aktualnej sytuacji społeczno-kulturowej w celu odczytania potrzeb wychowawczych, aby następnie na podstawie stałych tez antropologicznych proponować działania wychowawcze.

Tytułowe pytanie tych rozważań: „uczeń czy książka?” ma zwrócić uwagę na podmiotowy, personalistyczny charakter etyki wychowawczej Woronieckiego. Powtórzmy to pytanie za Woronieckim, który podejmując refleksję nad kształtem systemów oświatowych w Polsce po I wojnie światowej, rozpoczął dyskusję nad kryterium oceny kwalifikacji zawodowych profesorów akademickich i upominał się o docenienie zdolności dydaktycznych (Woroniecki 2008c). Nie liczba opublikowanych książek, ale umiejętność budowania relacji mistrz-uczeń powinna być, zdaniem Woronieckiego, fundamentem dla edukacyjnej i wychowawczej działalności uniwersytetów. Pedagog dostrzega w tym drogę do realizacji dobra osobowego i społecznego: moralno-intelektualny rozwój człowieka warunkuje rozwój kulturowy społeczności, której jest on członkiem.

Podążając tropem pedagogicznej myśli Woronieckiego, zajmiemy się kolejno kwestiami 1) kształtu wychowania, który Woroniecki proponuje oraz 2) aplikacji jego teorii do współczesnych potrzeb wychowawczych. Naszej analizie towarzyszy pytanie o aktualność myśli Woronieckiego w sytuacji przewartościowań związanych z obecnymi przemianami społeczno-kulturowymi.

\section{Sprawności moralne jako fundament wychowania}

Trzeba pamiętać, że zaproponowany przez Woronieckiego model rozwoju człowieka wyrasta z wielowiekowego dziedzictwa myśli chrześcijańskiej, na które składała się zarówno refleksja filozoficzna, jak i teologiczna, zogniskowana wokół Ewangelii. Wśród filozoficznych wyznaczników jego pedagogiki znajdują się np.: wyjątkowa wartość człowieka jako osoby, jego duchowo-cielesna struktura, a także przygodność i potencjalność ludzkiego bytu, celowość życia i działania oraz znacząca rola religii w rozwoju moralnym, w szczególności teoria sprawności moralnych. Współczesna kultura mocno orientuje człowieka na różnego rodzaju umiejętności i sprawności, widząc w nich sposób na realizowanie się ludzkiej wolności w przestrzeni społecznej. Do kluczowych pojęć we współczesnym słowniku opisującym rozwój człowieka należy słowo „kompetencje”. Podpowiedź, którą współcześni pedagodzy mogą usłyszeć od Woronieckiego, sugeruje, żeby

1 Jacek Woroniecki (1878-1949), dominikanin, teolog, filozof, pedagog, rektor UL (przedwojenny KUL), profesor Collegium Angelicum - znacząca postać życia religijnego, kulturalnego okresu międzywojnia („Niedziela” 2006). Na temat spuścizny pisarskiej Woronieckiego, zob. Filipiak 2000; Majewska 2006; Wistuba 2011. 
sprecyzować pojęcie kompetencji w dziedzinie moralnej i odkryć ich fundamentalną rolę dla osobowego spełnienia.

Woroniecki pojmuje sprawność moralną tak, jak robi to filozofia klasyczna: jako cnotę lub wadę (Sth, 1-2, q. 55 i 71; Woroniecki 1986, s. 338). Przedmiotem wychowania jest sprawność samodzielnego postępowania zgodnie z prawem moralnym (Woroniecki 1986, s. 332). Według pedagoga sprawności moralne uzyskują swoją kwalifikację w zależności od tego, czy są zgodne z prawem moralnym, czy nie. Autor wyjaśnia to w następujący sposób: „o ile pierwsze nam ułatwiają uczynki, odpowiadające wymaganiom naszej rozumnej natury i jej przeznaczenia, o tyle drugie przeciwnie, ułatwiają nam uczynki, które się sprzeciwiają właściwemu przeznaczeniu naszej duszy, a zaspokajają dążenia poszczególnych jej władz. [...] jak jedne, tak i drugie sprawiają, że pewne uczynki szybciej, łatwiej i bez wahania spełniamy, nadają bowiem one naszym władzom psychicznym pewną wewnętrzną determinację, która sprawia, że w odpowiednich warunkach człowiek ma raczej skłonność tak postąpić, a nie inaczej, że łatwo się zastosowuje do wymagań moralnych lub też równie łatwo się z nimi rozmija" (Woroniecki 1986, s. 341).

Specyfiką sprawności moralnych, w przeciwieństwie do innych ludzkich sprawności (tj. intelektualnych czy technicznych), jest polaryzacja ludzkiej aktywności: między cnotą a wadą toczy się nieustanne zmaganie. Każda stagnacja czy zaniedbanie w życiu moralnym pracują na rzecz rozwoju wad (Woroniecki 1986, s. 342). Ponadto specyfiką sprawności moralnych jest ich wzajemna zależność (Woroniecki 1986, s. 343). Woroniecki zaznacza, że „cnót moralnych nawet na chwilkę zaniedbać nie można, wciąż bowiem trzeba nimi regulować postępowanie. Bez roztropności, wytrwałości, umiarkowania, uczciwości, najdrobniejszego uczynku jak należy spełnić nie można; powinny one być czynne w każdym momencie naszego życia. Tam, gdzie ich nie ma, muszą prędzej czy później powstać wady, które będą na bieg postępowania moralnego coraz silniej wywierać swój zabójczy wpływ. Wobec wewnętrznej solidarności, łączącej wszystkie cnoty, brak jednej ma nie tylko lokalne znaczenie przez to, że na jej miejsce wyrasta wada, ale i wywiera destrukcyjny wpływ na inne cnoty, z których każda w wysokim stopniu jest zależna od moralnego rozwoju wszystkich innych" (Woroniecki 1986, s. 343).

Wspomniany związek między sprawnościami moralnymi Woroniecki proponuje nazwać pojęciem „charakter moralny”, gdyż wyraża się on w spójności moralnego postępowania człowieka (Woroniecki 1986, s. 373). W związku z tym kompetencję moralną należałoby widzieć bardziej jako zespół cnót, niż cnotę pojedynczą, a proces jej osiągania jako wypracowanie uzdolnień do wybierania dobra moralnego, czyli wychowanie. Dobrze ukształtowany charakter nadają działaniu stałość, sprawny umiar w poszczególnych dziedzinach i jednolity kierunek do naczelnego celu życia (Woroniecki 1986, s. 382-386). Można więc przyjąć, że cel wychowania urzeczywistnia się w uzyskaniu kompetencji moralnej, a strukturę wychowawczą człowieka wyznaczają cnoty. 
Woroniecki określa cnoty jako „stałe usposobienie i usprawnienie wszystkich władz [duchowych - dop. M.B.] do działania zgodnie z rozumem" (Woroniecki 1986, s. 373-374). Jakkolwiek działanie cnotliwe - ze względu na niezmienność ludzkiej natury - ma ogólnie określony kierunek, to niesie w sobie także olbrzymią różnorodność (Woroniecki 1986, s. 330-331). Współczesna pedagogika znajdzie więc u Woronieckiego bliskie jej pojęcia indywidualizacji i bogactwa rozwoju psychicznego człowieka. Ponadto uzyska cenne - ze względu na aspekt wolności człowieka - rozróżnienie między sprawnością a nawykiem (przyzwyczajeniem): pierwsze są „dziełem świadomego wysiłku i dalej też działają świadomie”, a drugie powstają nieświadomie i działają automatycznie (odruchowo) (Woroniecki 1986, s. 334). Myśliciel wyjaśnia: „Cnota równie jak i wada tylko skłania, ale nie zniewala, i człowiek zawsze zachowuje wolność postąpienia przeciw temu, do czego one skłaniają. Pierwiastek świadomości jest tu ostoją wolności” (Woroniecki 1986, s. 334).

Jednym słowem cnota to sprawność w działaniu moralnym: doskonali możność działania moralnego. Składa się na nią nie tylko gotowość do spełniania jakiegoś działania, ale także siła wyzwalająca czyn (Woroniecki 1986, s. 333). Ten drugi aspekt jest szczególnie istotny ze względu na rozumienie doskonałości człowieka. Cnota polega na dynamice miłości, dzięki której człowiek zwraca się ku prawdziwemu dobru. W związku z tym pierwsza sprawa, na którą należy zwrócić uwagę, rozważając dziś problem kompetencji moralnych, o ile wiąże się go z rzeczywistością cnoty, to konstatacja, że życie moralne nie ma natury statycznej.

Woroniecki jest daleki od idealizowania dynamiki życia moralnego człowieka i zaznacza, że ludzki charakter to rzeczywistość niedokonana i podlegająca ciągłemu rozwojowi. Autor zauważa, że „brak niektórych cnót, ani ich niecałkowity rozwój lub też niedostateczne i gruntowanie, ani wreszcie istnienie pewnych niewykorzenionych jeszcze całkowicie wad nie dowodzą braku dobrego charakteru, póki dążenie rozumu i woli świadomie zmierza do tej wewnętrznej harmonii, która z czasem ma coraz bardziej opanować działalność wszystkich naszych władz i na miejsce wad ująć je w karby dodatnich sprawności moralnych. Praca ta całkowicie nigdy ukończona nie będzie” (Woroniecki 1986, s. 384). I za chwilę dodaje: „Nie tyle więc dobro lub zło, cnoty i wady, jakie w sobie mamy, świadczą o dobrym lub złym stanie charakteru, ile nasz stosunek do nich i ten wysiłek lub brak wysiłku, aby rozwojem własnych sił moralnych pokierować jak należy i związać razem w jeden mocny charakter" (Woroniecki 1986, s. 384).

W związku z tym można przyjąć, że człowiek odznaczający się kompetencjami moralnymi to człowiek dobrego charakteru, a więc ktoś, kto świadomie zmierza do wewnętrznej harmonii. Istotą jego kompetencji jest więc moralna czujność i chęć działania zgodnie z zasadami moralnymi.

Z filozoficzno-teologicznej etyki Woronieckiego dla współczesnej pedagogiki płynie przede wszystkim jasne wskazanie, aby struktury wychowania opierać na systemie cnót, rozumianym jako model integrowania uczuciowości i umysłowości człowieka. Według Woronieckiego jest to jedyna droga do urzeczywistnienia 
w człowieku wolności i do jej ochrony. Autor zauważa: „Wychowanie personalistyczne na tym właśnie polega, aby nieświadomą swych celów i zadań jednostkę ludzką, czyli indywiduum, przetworzyć w samodzielną osobistość, umiejącą sprawnie władać w pełni świadomości wszystkimi swymi uzdolnieniami. Osobowość ludzka powinna się skrystalizować w postaci charakteru, gdyż on jeden może jej dać dosyć mocy, zarówno aby się oddać ofiarnie na usługi społeczeństwa, jak i aby nie pozwolić się przez nie pochłonąć i zniszczyć”. (Woroniecki 1986, s. 384)

Zaproponowany przez Woronieckiego model wewnętrznej formacji moralnej człowieka wydaje się nadal aktualny. Badacze współczesnej kultury, np. Herbert Marcuse, opisując obyczajowość nowoczesnego człowieka, podkreślają, że masowa kultura hamuje rozwój świadomości i sumienia (Marcuse 1991, s. 300-301). Zalew produkcji przemysłu informacyjnego, rozrywkowego niesie ze sobą wyznaczone postawy i obyczaje, preferowane reakcje intelektualne czy emocjonalne. Marcuse diagnozując społeczeństwo postindustrialne, zaznaczał, że współczesny człowiek karmi się fałszywą tożsamością płynącą z mediów, reklamy, indoktrynacji. W związku z tym trudno nie dostrzec, że kształtowanie wrażliwości moralnej to ciągle kluczowe zadanie pedagogiczne. Potwierdzają to także wskazania płynące z badań nauk społecznych. W ankiecie przeprowadzonej wśród pracodawców zatrudniających absolwentów Uniwersytetu Warszawskiego kryterium „kultura osobista” było wymieniane jako znaczący element „umiejętności miękkich” - potrzebnych w pracy z ludźmi (Raport..., 2014, s. 60). Fachowa wiedza i profesjonalizm potrzebują oparcia w silnym charakterze. Woroniecki dostrzegał wyraźną zależność tych dwóch czynników. Obserwując sytuację społeczno-kulturową Polski okresu międzywojnia, wskazywał na konieczność łączenia akcji wychowawczej i oświatowej, ponieważ - jak podkreślał - dopiero wychowanie daje umiejętność właściwego używania zdolności intelektualnych oraz nabytych wiadomości, a wręcz decyduje o rzeczywistej wartości wykształcenia (Woroniecki 2008a). Zauważał jednocześnie, że akcja wychowawcza nie może polegać tylko na teoretycznym przekazywaniu wiadomości na temat wychowania, ale wymaga praktycznej pracy wychowawczej i mocnego autorytetu wychowawcy (Woroniecki 2008a). Polski pedagog podkreśla wręcz, że głównym czynnikiem w wychowaniu jest moralna wartość samego wychowawcy, z kolei oddanie się pracy wychowawczej wymaga od wychowawcy czuwania nad własnym życiem moralnym (Woroniecki 2008b). To ważna uwaga i warta przypomnienia w czasach, gdy w różnych dziedzinach kultury obserwujemy tendencje do zastępowania autorytetów jawnych autorytetami anonimowymi (Fromm 2005).

Woroniecki dostrzega wagę bezpośrednich relacji osobowych w procesach wychowywania i edukacji. W artykule Uczeń czy książka? z 1918 roku, poświęconym problemowi kształcenia akademickiego i nauczycielskiego w powstającym państwie polskim, zwraca uwagę, że: „dla całokształtu kultury narodowej, dla roli, jaką szkolnictwo będzie miało w niej do odegrania, kult żywego nauczania będzie miał wprost pierwszorzędne znaczenie. Da on nam z czasem na wszystkich stopniach 
nauczania pracowników gorąco przywiązanych do swego zawodu i przekonanych, że najciekawszy proces na świecie to rozwój umysłu i serca ludzkiego, a najpiękniejsze zajęcie to umiejętne kierowanie tym rozwojem. Ars atrium regimen animarum («sztuką ze wszystkich najwyższą jest kierowanie duszami»)" (Woroniecki 2008c).

Bez wątpienia pilnym zadaniem dla współczesnych teoretyków i praktyków wychowania jest śledzenie bieżącej dyskusji filozoficznej, toczącej się wokół etyki cnót (nazywanej też etyką charakteru), a uznawanej dziś za jedną z ważniejszych teorii etycznych (Szuta 2013). Woroniecki (podobnie jak współcześni etycy cnót) kształtował swoją teorię w opozycji do kantyzmu i utylitaryzmu. Ocena czynu według polskiego pedagoga, tak jak u współczesnych etyków cnót (np. Michaela Slote'a czy Rosalinda Hurtsthouse'a), dokonuje się ze względu na kondycję moralną sprawcy. Człowiek dobry moralnie (powiedzmy: posiadający moralne kompetencje) jest sprawcą moralnie dobrego działania. Warte oddzielnego badania jest szczegółowe przeanalizowanie różnic występujących w rozumieniu struktury moralnego działania u Woronieckiego i współczesnych przedstawicieli nurtu etyki cnót. $\mathrm{Na}$ pewno będzie ona wynikała $\mathrm{z}$ różnic na poziomie ontologiczno-epistemologicznym. Woroniecki był tomistą, a więc uznawał istnienie obiektywnych zasad moralnych i doceniał rolę wiary w wewnętrznej formacji człowieka. Zwracał uwagę m.in., że dzięki czynnemu życiu religijnemu człowiek uzyskuje pogłębione spojrzenie na ważne dla moralności problemy: celowość życia, relację z Bogiem i społecznością (Woroniecki 2002). Niemniej jednak etyka autora, podobnie jak etyka współczesnych etyków cnót, jest zbudowana wokół podmiotu moralnego, a nie wokół analizy abstrakcyjnych zasad. W centrum etyki Woronieckiego stoi człowiek, a nie zbiór praw.

\section{Społeczeństwo nowoczesne a problem wartości}

Historycznie koncepcja społeczeństwa nowoczesnego sięga czasów oświecenia, w szczególności wiąże się z takimi wydarzeniami, jak narodziny kapitalizmu w Anglii, rewolucja francuska (1789-1799) czy uchwalenie konstytucji Stanów Zjednoczonych Ameryki (1787) - wzoru dla wielu konstytucji na świecie. Podstawy nowoczesnych społeczeństw stworzyły nie tylko zmiany polityczne, lecz także ekonomiczne i techniczne oraz związane z nimi procesy industrializacji i urbanizacji. Rozpoczęty u schyłku XVIII wieku proces trwa, a jego obecna faza nazywana jest nowoczesnością późną czy wręcz (po)nowoczesnością, dla podkreślenia różnic w stosunku do fazy wcześniejszej - industrialnej (Krzysztofek, Szczepański 2005, s. 55-90).

Jednym z motorów współczesnych przemian jest postęp naukowo-technologiczny. Przełom następuje już w połowie XX wieku. Charakteryzuje go wyraźne odejście od stosunków pracy właściwych przemysłowi wytwórczemu na rzecz usług, takich jak: handel, finanse, administracja, edukacja, ochrona zdrowia, rekreacja itp. (Krzysztofek, Szczepański 2005, s. 78-79). Badacze wskazują, że społeczeństwo postindustrialne zorientowane jest na relacje społeczne i porządek społeczny, podczas 
gdy o strukturach społeczeństwa industrialnego decydowały inne czynniki, a mianowicie technika i porządek techniczny. W literaturze przedmiotu znajdziemy kolejne wyróżniki nowoczesności: otwartość (Popper 1993, s. 194-199), ryzyko (Beck 2002, s. 65), dostęp do informacji i globalność (Bauman 2006; Giddens 2010, 72-99; Krzysztofek, Szczepański 2005, s. 186-231). Społeczeństwo (po)nowoczesne jest więc społeczeństwem otwartym, społeczeństwem ryzyka, społeczeństwem informacyjnym i globalnym.

Podkreśla się, że automatyzacja pracy i technizacja życia, postępujące na coraz większą skalę od lat 50., pozwalają ludziom poświęcać coraz więcej czasu pasjom i rozrywkom; wiedza z kolei i jej przetwarzanie stają się cennym dla gospodarki towarem. Jednym słowem rytm społecznego życia wyznaczają praca i konsumpcja, a pozycję społeczną człowieka określają jego zdolności nabywcze. Wśród wartości cenionych przez współczesnych ludzi znajdą się m.in.: jakość życia, zdrowie, sprawność fizyczna, bogactwo doznań, życie towarzyskie, ale przede wszystkim różnorodność (Giddens 2014, s.168).

Czasy (po)nowoczesności naznaczone są także przez wiele innych wydarzeń, procesów, które odciskają się na kształcie życia jednostek i decydują o społecznych relacjach. Pojawiają się mianowicie nowe formy komunikacji i telekomunikacji, rozbudowane siatki zależności ekonomicznych, politycznych i kulturalnych, co nie pozostaje bez wpływu na przyspieszenie procesów globalizacji i uniformizacji świata. Do symboli przemian społecznych, dokonujących się pod wpływem nowych technologii, należą: komputer osobisty, internet czy cyfrowa rzeczywistość, otwierająca przed człowiekiem świat wirtualny (Krzysztofek, Szczepański 2005, s. 187). U podstaw nowoczesnego społeczeństwa leżą prawa jednostki i wolność stowarzyszeń. Dla czasów (po)nowoczesnych charakterystyczne są ponadto jawność kwestii społecznych, możliwość toczenia demokratycznych debat wokół spraw ważnych społecznie, ochrona praw mniejszości oraz przeprowadzania zmian politycznych na drodze pokojowej (Popper 1993, t. 1, s. 194-199; Giddens 2004). Szeroki udział społeczeństwa w sprawowaniu władzy idzie dziś w parze z pluralizmem instytucji politycznych i świeckością państwa.

Oczywiście przemiany społeczne dokonujące się w ciągu dwóch ostatnich stuleci były przedmiotem refleksji wielu ważnych badaczy, którzy próbowali określić zbiór cech definiujących nowy typ społeczeństwa, najczęściej przez skonfrontowanie go z wcześniejszymi formami życia społecznego, tzw. tradycyjnymi. Taką ocenę prezentowali m.in.: August Comte (1798-1857), Karol Marks (1818-1883), Herbert Spencer (1820-1903), Henry S. Maine (1822-1888), Ferdinand Tönnies (1855-1936), Émile Durkheim (1858-1917), Max Weber (1864-1920), Robert Redfield (1897-1958) czy Talcott Parsons (1902-1979), Karl Popper (1902-1994), Daniel Bell (1919-2011). Należał do nich także Jacek Woroniecki. Jego refleksja rodziła się na podstawie obserwacji przemian społeczno-kulturowych pierwszej połowy XX wieku, ze szczególnym uwzględnieniem przemian w Polsce. Kulturowy punkt odniesienia w twórczości Woronieckiego - stawiane przez niego diagnozy potrzeb 
wychowawczych - bez wątpienia straciły dziś na aktualności. Niemniej jednak intelektualny ładunek treści filozoficznych nadal jest cenny, np. jako narzędzie eksplanacyjne ludzkiego działania moralnego. Określenie aktualnych potrzeb wychowawczych wymaga rejestracji zachodzących zjawisk społecznych. Z tego względu współczesny pedagog potrzebuje zarówno wiedzy z zakresu nauk społecznych, psychologii, jak i filozofii.

W filozoficznej refleksji Woronieckiego wyraźnie wybrzmiewa teza, że rozwój moralny jest gwarantem wewnętrznej wolności człowieka, a to, co nazwaliśmy kompetencją moralną, ma znaczenie dla kształtu relacji społecznych, także w warunkach demokratycznych. W katalogu cech definiujących społeczeństwo nowoczesne umieszcza się następujące: indywidualizm, zróżnicowanie światopoglądowe i bogactwo możliwych do realizacji zainteresowań zawodowych, edukacyjnych, sposobów życia oraz tzw. ruchliwość społeczną, czyli otwarty dostęp do ról i grup społecznych na podstawie zasad sprawiedliwości i równości (Giddens 2010). Status społeczny człowieka zależy zatem od jego indywidualnego wysiłku i kompetencji zawodowych. Te wyznaczniki nowoczesności potrzebują powiązania z dziedziną wartości moralnych, o czym przekonują nie tylko współcześni pedagodzy, ale i etycy, w tym etycy cnót (np. Alistair MacIntyre). Otwartość jako zasada relacji społecznych skutkuje silną konkurencyjnością na rynku pracy i brakiem poczucia bezpieczeństwa materialnego (Popper, t. 2, s. 293). W tych warunkach kulturowych wychowanie moralne staje się elementem kluczowym. Czujność moralna, o której pisał Woroniecki, stanowi najlepszą ochronę osobowej godności człowieka. Zadanie współczesnych pedagogów, o ile chcą podjąć myśl etyki wychowawczej Woronieckiego, polega m.in. na ciągłym przypominaniu w dyskursie publicznym o słuszności łączenia edukacji i wychowania. Przyjmowanie odpowiedzialności za własne życie nie dokona się tylko przez stałe doskonalenie kwalifikacji zawodowych, ale przede wszystkim dzięki formacji sumienia. Z tego względu wartościami społecznie nośnymi nie mogą być tylko edukacja, kursy dokształcające i samodoskonalenie zawodowe, ale przede wszystkim cnoty jako stałe wyznaczniki kultury wewnętrznej człowieka. Woroniecki wiele na ten temat pisał. Zwracał przy tym uwagę na rolę takich instytucji wychowawczych, jak: rodzina, Kościól, organizacje młodzieżowe i oświatowe (np. Woroniecki 2008a i b).

Pomoc człowiekowi w kształtowaniu przestrzeni jego wewnętrznej wolności to wręcz wymóg, który wskazuje pedagogom kierunek przemian społecznych doby (po)nowoczesnej. Nastawienie na przewidywalność i racjonalność skutkuje m.in. postępującą biurokratyzacją oraz wysoką homogenicznością pracy. Pojawia się więc realne zagrożenie dehumanizacji stosunków społecznych. Realizacja postulatu wychowania do wartości musi nadążać za dynamiką zmian obyczajowych. Obserwujemy, że zmiana może dotykać dziś nie tylko gustów, lecz także wzorów moralnych, nie tylko stylów w sztuce, ale i form życia rodzinnego. Wiadomo, że stymulowanie tych zmian w celu stopniowego eliminowania postaw niepożądanych i formowania osobowości nowoczesnej powierza się inżynierii społecznej (Jones 
2013; Goldberg 2007). Dlatego na szczególną uwagę w otwartych demokratycznych debatach społecznych zasługują wdrażane programy edukacyjne.

Polska pedagogika, doświadczona ideologią totalitaryzmu komunistycznego, uwrażliwia wprawdzie opinię społeczną na złożoność procesu kształtowania w człowieku wewnętrznej wolności, niemniej jednak powinna stale reflektować antropologiczne podstawy tego, co jest uznawane za wyznaczniki nowoczesnej osobowości. Według socjologów składają się na nią m.in.: rozbudowana potrzeba osiągnięć, skłonność do podejmowania ryzyka ze świadomością konsekwencji, innowacyjność, analityczność w ocenie własnych działań, dynamiczność, potrzeba poznawcza, współzawodnictwo, a także liberalno-demokratyczny światopogląd, zdolność empatii, twórczy nonkonformizm, otwartość na nowe doświadczenia i gotowość do świadomej akceptacji zmiany, zdolności do zbierania informacji o faktach oraz korzystania $z$ wiedzy w podejmowanych działaniach, umiejętności planowania i kalkulacji (w sferze osobistej i społecznej), umiejętności techniczne i rozumienie logiki procesów produkcyjnych oraz zasad podejmowania decyzji na szczeblach podstawowych, wiara w możliwość opanowania przyrody i ludzkiego organizmu, wysokie aspiracje oświatowe i zawodowe, zorientowanie na przyszłość, uniwersalizm i optymizm, rezygnacja $z$ fatalizmu i wiary w przeznaczenie oraz świadomość godności każdego człowieka wyrażająca się w postawach szacunku, a także dbałość o zdrowie (Krzysztofek, Szczepański 2005, s. 51-54). Należy pamiętać, że wszystkie wymienione cechy uzyskują swoją wartość edukacyjną dopiero w połączeniu z kompetencjami moralnymi. Potwierdzenie tej zależność znajdziemy w publikacjach pedagogicznych Woronieckiego.

Fenomen społeczeństwa (po)nowoczesnego wciąż budzi różne refleksje krytyczne. Etos konkurencji i efektywności zmuszają nas do zastanowienia się nad sensem prawości poza ustaleniami prawnymi czy zapytania o zwykłe poczucie przyzwoitości i wartość bycia dobrym człowiekiem. Racjonalizacja międzyludzkich relacji, wprawdzie użyteczna w swojej skuteczności, nie służy jednak budowaniu wspólnoty, ale sankcjonuje anonimowość i atomizację społeczeństwa. Machina biurokratyczna, jakkolwiek gwarantuje przewidywalność działań społecznych, tłumi jednocześnie ich spontaniczność i wolność. Dostępność dóbr nie wyeliminowała jaskrawych podziałów społecznych: bariery w konsumpcji powodują stawianie równie mocnych jak wcześniej barier społecznych, także w tzw. krajach rozwiniętych (Giddens 2010, s. 330-365). Adam Płachciak zauważa: „Społeczeństwo ponowoczesne jest podzielone na dwa światy. W pierwszym jednostka jest totalnie mobilna, bez większych trudów potrafi przemieszczać się w czasie i przestrzeni, tak realnie, jak i wirtualnie. Świat ten jest kosmopolityczny, eksterytorialny, zarządzany przez ludzi biznesu oraz menadżerów kultury. W świecie zaś drugim jednostka ograniczona jest więzami lokalnymi, które żądają od niej biernej zgody na zachodzące zmiany. Izolacja ta staje się bardziej dotkliwa, kiedy za sprawą mediów ukazywana jest niemalże w sposób natrętny możliwość wirtualnego przekraczania przestrzeni, która ciągle jest nie do pokonania w rzeczywistości niewirtualnej. Wspólny element 
obu światów stanowi nadmiar czasu. W pierwszym jego konsekwencją jest nuda, w drugim - frustracja i agresja" (Płachciak 2008, s. 195).

Erich Fromm diagnozując w wielu swoich książkach mentalność człowieka w pierwszym okresie postindustrialnej nowoczesności, wskazuje, że wektor skierowany w stronę materializmu oraz konsumpcji kłóci się z naturalnym dla człowieka pragnieniem wolności i miłości (np. Fromm 1996; 2014). Podobne wnioski o niebezpieczeństwach płynących ze zbyt jednowymiarowego życia, tzn. skoncentrowanego tylko na pracy i konsumpcji, formułuje w tym czasie Herbert Marcuse: „W krajach nadrozwiniętych coraz większa część ludności staje się jakby jednym potężnym, zahipnotyzowanym audytorium - trzymanym na uwięzi nie przez totalitarny reżim, lecz przez swobody obywateli" (Marcuse1991, s. 300).

Można powiedzieć, że przeskalowany konsumeryzm odbiera wartość osobie kosztem rzeczy, a doraźne cele, których wielka różnorodność jest dziś w zasięgu człowieka, mimo że cenne same w sobie, ulegając absolutyzacji, stają się zagrożeniem dla ludzkiej wolności.

W obecnej fazie (po)nowoczesności kwestia odzyskania dla świadomości społecznej uniwersalnego i transcendentnego spojrzenia na ludzkie życie - ważnego dla realizowania się w człowieku wolności i budowanych na niej relacji międzyludzkich - pozostaje aktualna. Wprawdzie przyzwolenia na obecność czynnika religijnego w kulturze jako zabezpieczenia wartości egzystencjalnych nie można zanegować, to jednak trudno znaleźć wyraźne azymuty i uzasadnienia metafizyczne (Boużyk 2013). Panuje przekonanie, że kulturze należy się ochrona przed dominacją jakiejś jednej religii (Delsol 2001), metafizyka z kolei, z jej „mocną myślą”, została przez filozofię współczesną ostatecznie rozliczona i pozbawiona intelektualnej atrakcyjności (Kołakowski, 1990). W tych warunkach kulturowych na ponowne zainteresowanie pedagogów zasługuje wszelka refleksja antropologiczna, która próbuje łączyć przestrzenie życia moralnego i religijnego, a więc także refleksja Woronieckiego. Znajdziemy u niego przede wszystkim dwa rozróżnienia, które mogą być stosowane jako klucz do wyjaśnienia zależności istniejących między religią a moralnością. Pierwsze dotyczy odrębności religii nadprzyrodzonej w stosunku do religii naturalnej, a drugie - odrębności moralności nadprzyrodzonej w stosunku do moralności naturalnej. Woroniecki jest zdania, że moralność przyrodzona może być przynależna człowiekowi do pewnego stopnia bez religii objawionej, niemniej jednak potrzebuje odniesienia do religii naturalnej. Myśliciel zwraca ponadto uwagę, że postępowanie człowieka, także w dziedzinie nadprzyrodzonej, opiera się na moralności przyrodzonej. Moralność nadprzyrodzona może natomiast stanowić cenne wzmocnienie dla moralności przyrodzonej (Woroniecki 2002). Trzeba pamiętać, że rozwiązanie proponowane przez polskiego pedagoga jest charakterystyczne dla tomistycznej koncepcji komplementarności wiary i rozumu $\mathrm{w}$ dziedzinie poznania.

Uwzględnienie wspomnianej zależności między religią a moralnością, w połączeniu ze zindywidualizowaną strukturą wychowania, właściwą etyce charakteru, 
wydaje się trafiać w zapotrzebowania współczesnego człowieka: w jego pragnienie samodzielnego stanowienia o sobie, odkrywania własnej tożsamości, twórczego i odpowiedzialnego przeżywania swojego życia. Anthony Giddens diagnozując aktualny stan kultury, posługuje się określeniem „epoka superróżnorodności”, zauważając, że większość populacji nie identyfikuje się dziś z pojedynczą grupą społeczną. W związku z tym wzorów zachowań jest wiele, a tożsamości stają się płynne i mieszane (Giddens 2014, s. 168). W tej sytuacji ważne jest akcentowanie przez pedagogów zagadnienia autowychowania i roli nieanonimowych autorytetów moralnych. Pedagogiczna myśl Woronieckiego to w tym zakresie źródło cennych inspiracji. Etyka wychowawcza, którą pedagog opracował, w centrum doświadczenia moralnego stawia osobę z całym bogactwem jej przeżyć emocjonalnych i poszukiwań prawdy o dobru. Cnoty, o których pisze Woroniecki, nie są celem samym w sobie, ale mają ułatwić człowiekowi realizację dobra, pójście za dobrem i przełamywanie własnego egoizmu.

Opracowana przez Woronieckiego etyka wychowawcza była propozycją odpowiedzi na potrzeby społeczeństwa w odradzającym się państwie polskim, swego rodzaju kompasem moralnym, kodeksem systemu wychowania. Jakkolwiek dziś krajobraz dostępnych nam dóbr jest dużo bardziej urozmaicony niż na początku $\mathrm{XX}$ wieku, to główne przesłanie dla pedagogiki płynące z dorobku Woronieckiego pozostaje to samo: jest nią wartość ludzkiego życia, odczytana w kontekście ostatecznego celu ludzkiego życia. Pisze o niej następująco: „gdy się przyjrzymy poszczególnym choćby największym przedsięwzięciom naszego życia, takim np. jak wielka podróż, wybór zawodu, założenie rodziny przez związek małżeński, zorganizowanie przedsiębiorstwa przemysłowego lub handlowego itp., łatwo się przekonamy, że to, co im przyświeca, nie ma charakteru celu zupełnie ostatecznego. Względem poszczególnych czynności, przez które go osiągamy, przedstawia się on jako coś naczelnego, do czego tamte zmierzają i od których otrzymują jedność kierunku" (Woroniecki 1986, s. 67).

Konkluzja Woronieckiego nie pozostawia wątpliwości: „Widzimy tedy, że żadne z tych dóbr, które są pobudkami i przedmiotem naszych czynów w życiu doczesnym, nie może być celem ostatecznym, regulującym całe nasze postępowanie moralne, żadne $\mathrm{z}$ nich bowiem nie odpowiada warunkom dobra, którego posiadanie mogłoby nam dać prawdziwe, doskonałe, całkowite i trwałe szczęście, dostępne przy tym dla wszystkich" (Woroniecki 1986, s. 74).

Wychowanie charakteru jako oś pedagogicznej refleksji jest autentyczną potrzebą chwili. Wielu badaczy zwraca uwagę na nieprzejrzystość, niepewność i chaotyczność życia społecznego oraz na towarzyszące rozwojowi cywilizacyjnemu nowe formy ryzyka (Bauman 2006, s. 139-144; Giddens 2010, s. 243-278). Według Ulricha Becka podstawą solidarności w społeczeństwie (po)nowoczesnym przestał być głód, a stał się lęk (Beck 2002, s. 65). Naszym zdaniem sytuacja kulturowa wymusza na współczesnej pedagogice odczytanie sytuacji egzystencjalnej człowieka $\mathrm{w}$ perspektywie bardziej uniwersalnej. Oznacza to wyjście pedagogiki z ciasnego 
paradygmatu nauk społecznych i skierowanie jej w stronę myślenia humanistycznego, a w szczególności konieczność uwzględnienia w antropologii perspektywy metafizycznej, właśnie tak, jak robił to Woroniecki. Według niego praktyka wychowawcza miała być osadzona w realiach społeczno-kulturowych, przy zachowaniu wartości wyjaśniającej tezy metafizyczne dotyczące ludzkiej natury i ludzkiego działania. Woroniecki wielokrotnie podkreślał, że niepewność egzystencjalna jest środowiskiem moralnym służącym podejmowaniu przez człowieka decyzji, a silny charakter i prawość moralna mają decydujący wpływ na spełnienie osobowe i są podstawą sprawiedliwych relacji społecznych. Proponowana przez Woronieckiego etyka cnót ukierunkowuje pracę wychowawczą (i autowychowawczą) na osiągnięcie stanu wewnętrznej autonomii poprzez usprawnianie poszczególnych władz duchowych i indywidualnych skłonności wychowanka.

Według Woronieckiego wachlarz cnót organizują cztery cnoty kardynalne: umiarkowanie, męstwo, roztropność i sprawiedliwość. W refleksji pedagogicznej każdą z nich należy poddać dziś analizie z perspektywy aktualnych potrzeb wychowawczych. Jak dobrze wiadomo, kolejne zmiany w kształcie nowoczesności nie wyeliminowały problemu alienacji, biedy, wykluczenia społecznego, ujawniły tylko ich nowe formy. Konsekwencja w realizowaniu liberalnych zasad doprowadza do nieoczekiwanych paradoksów, $\mathrm{np}$. do tolerowania nietolerancji ze względu na zachowanie zasady tolerancji (Kołakowski 1984, s. 206). Problematyczna w realizacji okazuje się główna idea nowoczesności - idea równości (Sen 20oo, s. 45). Trwający w Europie kryzys imigracyjny pokazuje słabość kolejnego społecznego spoiwa: idei wielokulturowości. (Po)nowoczesność nie uporała się też z niebezpieczeństwem uprzedmiotowiania człowieka. W istniejących warunkach cywilizacyjnych jest ono związane choćby z użytkowaniem nowych technologii, biurokratyzacją, organizacją pracy nastawioną na wydajność i zysk, społeczną manipulacją i rzeczywistościami wirtualnymi (Lyotard 1998, s. 105-106; Giddens 2014, s. 474-511). Ze względu na wysoką specjalizację ról społecznych większość ludzi (użytkownicy nowoczesnych technologii i członkowie społeczności) pozostaje zależna od ekspertów, systemów komunikacyjnych i finansowych, międzynarodowych korporacji i organizacji itp. We wszystkich tych przestrzeniach można podjać wychowawczy wysiłek w celu ochrony dobra osoby, korzystając z przewodnika, jakim jest etyka cnót. Wzorem Woronieckiego, który dopasował wykład etyki klasycznej i jej zasadę człowieka „pięknego dobra” (kaloskagathos) do realiów życia społecznego okresu międzywojnia, współcześni pedagodzy mogą ponieść ten model w rzeczywistość współczesnej kultury.

Kończąc, zauważmy, że Woroniecki obserwował procesy społeczne, polityczne i kulturowe epoki nowoczesnej-industrialnej w ich przełomowym okresie: wyznaczonym dwiema wojnami światowymi. Wnikliwie analizował konsekwencje założeń filozoficznych w dziedzinach moralności i wychowania. W szczególności zwracał uwagę na niebezpieczeństwo, które rodził relatywizm, wyznaczający podstawy nowoczesnego myślenia, oddziałujący silnie na sfery wartości i postaw 
moralnych. Mimo że ostatnia wojna światowa i upadek systemów totalitarnych ujawniły dramatyczne konsekwencje tego modelu aksjologii, jego obecność w systemach liberalnych wydaje się ciągle być faktem (Kołakowski 1984, s. 206-216). Oczywiście relatywizm próbuje się dodatkowo uwarunkować, np. deklaracjami o ochronie praw mniejszości, humanitaryzmie, pluralizmie religii i kultur, niemniej jednak główne założenie - relatywizm prawdy - pozostaje, a nawet urasta do roli swoistego gwaranta wolności człowieka i demokracji. Przykłady kolejnych dziesięcioleci wskazują jednak, że generuje on chaos w sferze wartości kluczowych dla rozwoju człowieka. W związku z tym rodzi się potrzeba ponownego zwrócenia uwagi na problemy prawdy jako wartości obiektywnej czy fundamentalnych kwestii antropologicznych, takich jak duchowy i moralny wymiar ludzkiego bytu. Podstawą personalizmu pedagogiki Woronieckiego była m.in. teza o zdolności rozumu do poznania obiektywnej prawdy i związku, jaki istnieje między nią a dobrem moralnym. Dlatego zastanawiając się nad aktualnością pedagogiki polskiego myśliciela, należy przede wszystkim zapytać, czy dziś, w przestrzeni debat akademickich, istnieje szansa na ponowne pytanie o prawdę.

\section{Bibliografia}

Baumann Z. (2006). Globalizacja: i co z tego dla ludzi wynika, tłum. E. Klekot. Warszawa: PIW.

Beck U. (2002). Społeczeństwo ryzyka. W drodze do innej nowoczesności, tłum.

S. Cieśla. Warszawa: Wydawnictwo Naukowe Scholar.

Boużyk M.M. (2013). Wychowanie otwarte na religię. Polska Szkoła Filozofii Klasycznej o roli religii w wychowaniu. Warszawa: Wydawnictwo UKSW.

Delsol Ch. (2001). Bóg na wygnaniu, tłum. D. Zańko. „Znak”, nr 10, s. 9-23.

Fromm E. (1996). Zdrowe społeczeństwo, tłum. A. Tanalska-Dulęba. Warszawa: PIW.

Fromm E. (2014). Mieć czy być?, tłum. J. Karłowski. Poznań: Dom Wydawniczy Rebis.

Fromm E. (2005). O sztuce istnienia. Terapeutyczne aspekty psychoanalizy, tłum. R. Saciuk. Warszawa: Wydawnictwo Naukowe PWN.

Giddens A. (2010). Nowoczesność i tożsamość. „Ja” i społeczeństwo w epoce późnej nowoczesności, tłum. A. Szulżycka. Warszawa: Wydawnctwo Naukowe PWN.

Giddens A. (2004). Socjologia, tłum. A. Szulżycka. Warszawa: Wydawnictwo Naukowe PWN.

Giddens A. (2014). Europa burzliwy i potężny kontynent, tłum. O. Siara. Warszawa: Wydawnictwo Naukowe PWN.

Goldberg J. (2007). Lewicowy faszyzm. Tajemna historia amerykańskiej lewicy od Mussoliniego do polityki zmiany, tłum. L. Jęczmyk, J. Lang. Warszawa: Wydawnictwo Zysk i S-ka.

Jones E.M. (2013). Libido dominandi. Seks jako narzędzie kontroli społecznej, tłum. J. Morka. Wrocław: Wydawnictwo Wektory. 
Kołakowski L. (1990). Horror metaphysicus. Warszawa: Wydawnictwo Res Publica.

Kołakowski L. (1984). Samozatrucie otwartego społeczeństwa. W: tenże. Czy diabeł może być zbawiony i 27 innych kazań. Londyn: Aneks, s. 206-216.

Krzysztofek K., Szczepański M.S. (2005). Zrozumieć rozwój. Od społeczeństw tradycyjnych do informacyjnych. Katowice: Wyd. Uniwersytetu Śląskiego.

Lyotard J.-F. (1998). Postmodernizm dla dzieci. Korespondencja 1982-1985, przeł. J. Migasiński. Warszawa: Fundacja Aletheia.

Marcuse H. (1991). Człowiek jednowymiarowy. Badania nad ideologia rozwiniętego społeczeństwa przemysłowego. Warszawa: Wydawnictwo Naukowe PWN.

Popper K.R. (1993). Społeczeństwo otwarte i jego wrogowie, tłum. H. Krahelska, t. 1-2. Warszawa: Wydawnictwo Naukowe PWN.

Płachciak A. (2008). Moralne dylematy rozwoju społeczeństw ponowoczesnych, „Annales. Etyka w życiu gospodarczym”, nr 1, s.193-199.

Raport UW. Monitorowanie losów absolwentów uczelni wyższych z wykorzystaniem danych administracji Zakładu Ubezpieczeń Społecznych (styczeń 2014).

Sen A. (200o). Nierówności. Dalsze rozważania, tłum. J. Topińska, M. Kochanowicz. Kraków: Wydawnictwo Znak.

Niedziela M.L. (red.) (2006). Sługa Boży ojciec Jacek Woroniecki uczy. Warszawa: Wydawnictwo Gaudium.

Szutta N. (2013). Status współczesnej etyki cnót. W: J. Zborowski (red.). Etyka u schyłku drugiego tysiąclecia. Warszawa: Wydawnictwo Naukowe „Scholar”, s. 231-242.

Tomasz z Akwinu (200o). Skrót zarysu teologii (Sumy teologicznej) św. Tomasza $z$ Akwinu, red. (skrót i objaśnienia) F. W. Bednarski. Warszawa: Wydawnictwo Antyk.

Woroniecki J. (1986). Katolicka etyka wychowawcza, t. 1. Lublin: RW KUL.

Woroniecki J. (2002). Moralność a religia. W: tenże. U podstaw kultury katolickiej. Teksty zebrane. Lublin: Wydawnictwo Instytutu Edukacji Narodowej, s. 55-70.

Woroniecki J. (2008a). Oświata i wychowanie. W: tenże. W szkole wychowania. Teksty wybrane. Lublin: FSViIEN, s. 19-40.

Woroniecki J. (2008b). Społeczeństwo a wychowanie. W: tenże, W szkole wychowania. Teksty wybrane. Lublin: FSViIEN, s. 41-61.

Woroniecki J. (2008c). Uczeń czy książka?. W: tenże. W szkole wychowania. Teksty wybrane. Lublin: FSViIEN, s. 109-128.

\section{A STUDENT OR A BOOK? JACEK WORONIECKI'S PEDAGOGY AS A CLUE TO MODERN EDUCATION}

\footnotetext{
Abstract: The article considers the validity of Jacek Woroniecki's ethics in terms of its demand for the development of human character. The article consists of two parts. Part 1 focuses on the definition of moral skill as a virtue and Part 2 deals with the problem of
} 
moral skills confronted with a set of contemporary values. Exploring Woroniecki's solutions, the author attempts to define moral skills as a dynamic set of virtues, i.e. a developed ability to choose and protect the moral good. The author argues that the skill includes the readiness to perform a moral action and the action-liberating force. Given that such moral competence activates self-education and development of strong character, Woroniecki's ethics meet the needs of contemporary culture, which is characterised by a high degree of individualism. Furthermore, it emphasizes the need to embed the process of education in the strong moral authority of educators: in the educational system, a real relationship between the master and the student cannot be replaced by book knowledge.

Keywords: ethics of character, virtues, moral competence, modernity, personalism.

Maria M. Boużyk - doktor habilitowany nauk humanistycznych w zakresie filozofii, zatrudniona na Wydziale Nauk Pedagogicznych Uniwersytetu Kardynała Stefana Wyszyńskiego w Warszawie. W badaniach koncentruje się na problemach filozofii religii, antropologii filozoficznej i filozofii wychowania, a w szczególności na kwestii filozoficznego uzasadnienia otwarcia pedagogiki na wartości chrześcijańskie. Monografia autorska: Wychowanie otwarte na religię. Polska Szkoła Filozofii Klasycznej o roli religii w wychowaniu (Warszawa 2013).Adres mejlowy: m.bouzyk@uksw.edu.pl. 